\title{
TINJAUAN TEOLOGI SISTEMATIS-APOLOGETIS TERHADAP PANDANGAN ADOPSIONISME MENGENAI KETUHANAN YESUS
}

\author{
Hendrik Yufengkri Sanda \\ Sekolah Tinggi Teologi Injili Setia Siau \\ sandahendrik@gmail.com
}

\begin{abstract}
Jesus is a unique person because he has two natures, namely God and Human. The Bible explicitly teaches and testifies on this subject. But in fact, some views reject both His divine nature and even His humanity. These views have been around since Jesus' incarnation in the world until now. One of the teachings which classify as Christian heretics in the early centuries was the adoptionist view, which taught Jesus only human beings who adopt as children of God later. It means they reject the divinity and also the pre-existence of Christ as God before His incarnation. This study intends to criticize the adoptionist idea. The method used is qualitative research through a systematic-apologetic approach. The results showed that the view of adoption was wrong because it violated the principle of the divine nature of Jesus as the Bible teaches. Jesus is Lord from the beginning, not after His incarnation.
\end{abstract}

Keywords: Person of Jesus, God-human nature, Systematic-Apologetic, Adoptionism

\begin{abstract}
Abstrak. Yesus adalah pribadi yang unik sebab memiliki dua natur yakni sebagai Allah dan juga manusia. Alkitab secara eksplisit mengajarkan dan memberikan kesaksian mengenai pokok ini. Namun realitanya ada juga pandangan yang menolak baik natur keilahian-Nya bahkan juga kemanusiaan-Nya. Gagasan-gagasan demikian sebenarnya sudah ada sejak inkarnasi Yesus di dunia. Mulai dari pandangan para pemuka agama Yudaisme, para pemimpin gereja mula-mula, hingga di masa sekarang oleh para teolog agama-agama. Salah satu ajaran yang digolongkan sebagai bidat Kristen pada abad mula-mula adalah pandangan adopsionisme yang mengajarkan Yesus hanya manusia biasa yang kemudian diadopsi menjadi anak Allah. Jika demikian maka sama halnya menolak keilahian dan juga pre-eksistensi Kristus sebagai Allah sebelum inkarnasiNya. Penelitian ini bermaksud mengkritisi pandangan adopsionisme tersebut. Metode yang digunakan adalah penelitian kualitatif melalui pendekatan teologi sistematis-apologetis. Hasil penelitian menunjukkan bahwa pandangan adopsionisme sangat keliru karena menyalahi prinsip natur keilahian Yesus sebagaimana yang diajarkan Alkitab. Yesus adalah Tuhan dari sejak semula bukan setelah inkarnasi-Nya.
\end{abstract}

Kata kunci: Pribadi Yesus, Natur Ketuhanan-kemanusiaan, Sistematis-Apologetis, Adopsionisme

Kepercayaan Kristen adalah kepercayaan yang unik. Sebab inti dari keyakinan ini adalah meyakini Yesus Kristus sebagai Tuhan dan Juruselamat. Yesus adalah tokoh yang pernah hadir dalam sejarah dunia ini dan menjadi pusat penyembahan karena keyakinan ini. Tentu pengakuan iman ini menuai banyak 
kecaman dari berbagai agama non kristen. Kritikan-kritikan tajam datang dari para ilmuan dan filsuf. Bahkan sampai pada para teolog inklusivis dan pluralis di dalam kekristenan itu sendiri ada yang menyangsikan pengkuan ini. Pertanyaan yang sering dilontarkan adalah bagaimana mungkin Yesus yang dipercaya sebagai seorang manusia pada saat yang sama pula diyakini sebagai Allah juga? Bukankan itu adalah sesuatu yang paradoksal?

Sejak kehadiran dan pelayanan Yesus selama di dunia, Ia sudah mengalami penolakan dan penyangkalan akan natur keilahian-Nya baik dari para pemimpin agama Yahudi. Bahkan dalam peristiwa kematian, kebangkitan dan kenaikan-Nya ke sorga, dan pada zaman apostolik juga berita ini tetap saja disangsikan. Dengan berjalannya waktu, kira-kira 100-200 tahun setelah beberapa peristiwa agung dan bersejarah itu, terjadilah perdebatan-perdebatan yang hangat sampai memanas dari bapak-bapak gereja dalam membahas pokok iman ini. Bahkan sampai diadakan berkali-kali konsili agar mendapatkan konsesus untuk menyelesaikan persoalan kristologi dari berbagai pandangan yang menolak natur keilahian dan kemanusiaan Yesus yang dalam terminus teknikusnya dikenal dengan istilah "Bidat-bidat Kristen".

Dalam sejarah gereja mula-mula, pertikaian teologis mengenai pribadi Yesus sangat tajam. Ada pandangan yang menerima salah satu natur dan mengabaikan yang lainnya, begitu juga ada yang menerima kedua natur tersebut dan sebaliknya. Gereja benar-benar mengalami pergumulan teologis yang hebat untuk menyelesaikan persoalan-persoalan Kristologi di dalam ajaran Kristen sendiri. Pada akhirnya gereja perlu memutuskan pandangan yang sesuai dengan 
ajaran Alkitab dengan menolak berbagai pandangan yang salah serta dianggap sebagai bidat (heresy). Berikut ini beberapa pandangan yang keliru dan dianggap sebagai bidat karena menyalahi prinsip natur kemanusiaan dan keilahian bahkan yang menyalahi prinsip kesatuan kedua natur Yesus yakni: Sabelianisme (Modalisme), Doketisme, appolinarianisme (yang menyalahi prinsip natur kemanusiaan Yesus), Gnostikisme, Ebionisme, Arianisme (yang menyalahi prinsip Natur Keilahian Yesus), dan Nestorianisme dan Eutychianisme (Absorpsionisme) (yang menyalahi prinsip kesatuan kedua natur Yesus). (Ambarsari 2007).

Selain bidat-bidat yang telah disebutkan di atas, salah satu bidat yang muncul pada waktu itu juga adalah adopsionisme (mulai \pm thn $200 \mathrm{M}$ ). Adopsionisme (bahasa Inggris: Adoptionism) adalah paham yang menganggap bahwa Yesus adalah manusia biasa yang diadopsi menjadi Anak Allah. Ajaran ini muncul dari kelompok Kristen Ebionit. Kemudian ajaran ini dikembangkan oleh golongan Monarkisme Dinamis pada abad II dan abad III. Oleh karena itu, nama lain dari gerakan ini adalah Monarkisme Dinamis. Secara umum teori Adopsionisme adalah pengertian bahwa Kristus adalah seorang manusia biasa yang di“angkat” menjadi anak Allah lalu dikaruniai kuasa. Inilah ajaran yang dianut oleh kaum Kristen Ebionit. Ajaran ini pun dinyatakan sebagai ajaran sesat pada akhir abad ke-2 dan secara resmi ditolak dalam Konsili Nicea I.

Pada dasarnya adopsionisme adalah sebuah kesalah-pahaman terhadap pribadi Yesus yang berawal pada akhir abad ke II. Kaum Adopsionis menyangkali pre-eksistensi Yesus dan membantah keilahian-Nya. Pandangan ini mengajarkan 
bahwa Yesus telah menerima ujian dari Allah dan setelah lulus ujian dia menerima baptisan, lalu kemudian diberikan kuasa-kuasa supranatural oleh Allah dan diadopsi atau diangkat sebagai Anak Allah. Sebagai upah dari kesuksesanNya dan pribadi Yesus yang sempurna, Dia dibangkitkan dari kematian lalu diangkat ke dalam Allah Tritungal. Horton menyebutkan, pada hakikatnya adopsionisme mengajarkan bahwa Yesus pada dasarnya tidak ilahi. Ia justru telah diadopsi oleh Bapa — mungkin pada saat pembaptisan-Nya atau bahkan mungkin saat kelahiran-Nya. (Horton 2011).

Selain pandangan adopsionisme seperti Horton di atas, Wongso menjelaskan pandangan adopsionisme:

Kristus sebagai manusia yang diangkat sebagai anak Allah, tatkala Yesus dibaptis, Roh Kudus turun atas diri-Nya dan Allah mengatakan inilah Putera yang kukasihi, pada saat itu Kristus menjadi anak angkat Allah. Karena adanya kuasa Allah pada diri-Nya, maka teori ini juga disebut dynamism. Kuasa Tuhan ada pada diri-Nya hinga saat Ia tersalib dan berseru "Eli, Eli Lamasabatani, maka kuasa Allah telah meninggalkan diriNya, karena Tuhan tidak dapat disalib. Oleh sebab itu Ia menjadi Anak Allah dalam dunia; kuasa yang Ia dapat ketika Ia dibaptis telah lenyap tatkala Ia disalib. (Wongso 2001, 30).

Mendukung pandangan Horton dan Wongso di atas, Velduis lebih lanjut memberikan elaborasinya mengenai pandangan adopsionisme bahwa Yesus pada dasarnya seorang manusia biasa, yang pada suatu saat tertentu oleh pekerjaan istimewa dari Roh Kudus menjadi Anak Allah. Momen ini tentunya adalah pembaptisan olehYohanes Pembaptis (Mrk.1:9-11) Ketika Roh Allah turun ke atas Yesus dalam rupa seekor burung merpati dan suara Allah berkata:"Engkaulah Anak-Ku yang kukasihi kepada-Mulah Aku berkenan. (Velduis 2010). 
Yesus dianggap sebagai orang yang dipilih Allah bagi diri-Nya, seorang yang di dalam-Nya berdiam atau tinggal ke-Allah-an dan Roh Allah. Ada beberapa pandangan mengenai kapan Yesus diadopsi menjadi Anak Allah: pada saat baptisan misalnya Paulus dari Samosata, setelah kebangkitan dan setelah lulus pencobaan. Ayat-ayat Alkitab seperti Kis. 2:32-36 dengan gampang dibaca secara adopsianis. Pada abad ke-8 ajaran ini dihidupkan kembali oleh Felix dari Urgella. Menurutnya Kristus sebagai Logos memang adalah Anak Tunggal Allah secara alamiah, tetapi Kristus sebagai manusia menjadi Anak Allah karena adopsi. Yesus sebenarnya memiliki natur yang telah tercemar walaupun Ia tidak berdosa. Ketercemaran ini perlu supaya Yesus dapat dicobai dalam segala hal sama seperti kita. Tetapi ini berarti bahwa ketercemaran bukanlah dosa. Pandangan ini ditolak dalam Sinode Frankfort. (Pelikan 1993).

Pada abad ke- 18 ajaran ini muncul dalam pandangan Shleiermacher. Menurutnya, Yesus memang mempunyai bapak duniawi tetapi melalui suatu tindakan supranatural embrio Yesus disucikan dari dosa warisan. Pada abad ke-19 (sekitar 1830an) pandangan ini hidup lagi di Jerman oleh Menken dan di Inggris oleh Irving. Menurut Irving kemanusiaan Kristus setelah persatuannya dengan Logos masih tetap kemanusiaan yang berdosa, sebagai dukungan ia mengutip Roma 8:3, sama seperti sebelum persatuan itu terjadi. Namun karena Roh Kudus tinggal di dalam Dia maka Ia dapat mengalahkan semua pencobaan, bahkan ia sama sekali tidak memiliki keinginan untuk berdosa. (Rosner et al. 2000). Kemudian pada abad ke-20 jumlah teolog penganut pandangan ini menjadi lebih banyak lagi, a.l. James Dunn, John A. T. Robinson, Hendrik Berkhof, dll. Teolog- 
teolog seperti disebutkan di atas mendasarkan pemahaman mereka pada ayat-ayat PB, terutama Injil Yohanes, Surat-surat Paulus dan Kitab Ibrani bahwa kitab-kitab ini mengajarkan adopsianisme. (Macleod 1998).

Inti dari ajaran adopsionisme yakni Yesus dipandang sebagai manusia yang bijaksana, baik hati, melakukan perintah Allah dengan sempurna, dan taat kepada Allah. Oleh karena itu, Yesus diadopsi oleh Allah dan dipersatukan dengan Roh Allah. Yesus diangkat menuju tingkat ilahi sebagai Anak Allah. Setelah itu, Yesus disembah sebagai Tuhan. (Wellem 2004). Kaum adopsionis berpandangan bahwa kalimat: "Engkaulah Anak yang Kukasihi, kepada-Mu Aku berkenan" (Markus 1:11) dianggap sebagai formula penobatan raja atau pengangkatan anak (pada saat itu Yesus diadopsi sebagai Anak Ilahi). (Browning 2011).

Jika kita melihat sejarah perkembangan gereja maka doktrin mengenai Yesus sebagai Tuhan atau Anak Allah sampai abad XXI ini pun masih tetap mendapat sorotan yang tajam baik dari kaum adopsionis modern maupun secara khusus dari pandangan teologi agama-agama dan para teolog pluralis-inklusivis. Artinya dalam kubu kekristenan sendiri sudah ada perbedaan pendapat bagaimana lagi dengan keyakinan yang lain? Tentu ini menjadi peluang besar untuk menyerang ajaran kekristenan. Meskipun demikian kita masih beruntung memiliki Alkitab sebagai senjata ampuh untuk menangkal segala serangan dari keyakinan lain bahkan dari dalam kekristenan sendiri yang menolak keilahian Yesus. Dengan demikian melalui penelitian ini, peneliti berusaha mengkaji pandangan dari adopsionisme yang menganggap bahwa Yesus sebenarnya bukan Tuhan atau 
BONAFIDE: Jurnal Teologi dan Pendidikan Kristen

www.jurnal.sttissiau.ac.id/Volume 1/Nomor 1/Juni 2020/hal. 144-164

Allah namun diadopsi menjadi Anak Allah. Apakah benar demikian? Kita akan melihat apa jawaban Alkitab mengenai pokok ini.

\section{METODE PENELITIAN}

Penelitian yang digunakan adalah penelitian kualitatif dengan menggunakan pendekatan teologis-sistematis dan apologetis. Dengan adanya suatu metode dan prosedur penelitian, maka penulisan ini didasarkan pada penelitian kepustakaan yaitu dengan cara menelusurinya serta menelaahnya. (Nazir 2007). Sedangkan metode penelitian yang digunakan adalah metode analisis dan deskriptif secara sistematis. Analisis adalah penguraian atau kupasan suatu pokok atas berbagai bagiannya dan penelaahan bagian itu sendiri serta hubungan antar bagian-bagian untuk memperoleh pengertian yang tepat dan pemahaman arti keseluruhan. (Budiono 2005).

\section{HASIL PENELITIAN}

Melalui penelitian yang dilakukan, peneliti menemukan bahwa pandangan tdopsionisme dan teologi agama-agama benar-benar menyalahi prinsip natur keilahian Yesus sebagaimana yang diajarkan Alkitab bahwa Yesus adalah manusia sekaligus Tuhan (Allah) dalam satu pribadi. Pandangan ini hanya menitikberatkan kepada natur kemanusiaan Yesus yang kemudian diangkat menjadi Anak Allah. Konsekuensi logis dari pandangan ini adalah: Pertama: Menyangkali Keilahian Yesus (Sebelumnya Yesus bukan Allah), Kedua: menolak pre-eksistensi Yesus (eksistensi Yesus baru terjadi saat inkanasi bukan sejak dari awal atau kekekalan), Ketiga: menolak doktrin Trinitas atau Tritunggal, dan 
BONAFIDE: Jurnal Teologi dan Pendidikan Kristen

www.jurnal.sttissiau.ac.id/Volume 1/Nomor 1/Juni 2020/hal. 144-164

terakhir: Melemahkan ajaran dan kesaksian Alkitab (Firman Allah) sebagai kebenaran mutlak dan berotoritas yang mengajarkan tentang natur keilahian dan kemanusiaan Yesus. Sehingga penyangkalan akan keilahian Yesus tidak dapat diterima dan dianggap salah karena tidak seperti ajaran Alkitab bahwa Yesus benar-benar Tuhan dan manusia sejati (tanpa dosa).

\section{PEMBAHASAN}

\section{Pribadi Yesus: Natur Ilahi dan Manusia}

Berbeda dengan pandangan kaum adopsionis dan teologi agama-agama, para teolog reformed selain menekankan natur kemanusiaan Yesus, justru terus menekankan doktrin tentang natur keilahian Yesus sebagai Tuhan. Beberapa contoh pandangan di bawah ini akan menjadi representatif terhadap pandangan reformed yang dimaksud. Berikut ini sebagaimana yang dikemukakan oleh Bavinck dalam bukunya Reformed Dogmatics:

Sejak awal, kepercayaan bahwa Yesus adalah Kristus telah menjadi Jantung dan inti dari pengakuan Kristen. Dalam pandangan Alkitab, Yesus adalah perantara yang diurapi, yang memenuhi jabatan nabi, imam, dan raja. Dia adalah mediator sempurna antara Tuhan dan manusia karena dia sendiri adalah Tuhan yang sejati dan manusia sejati. (Bavinck 2011, 432).

Selain pandangan Bavinck di atas ada juga pandangan-pandangan lain,

Groenen menyatakan,

Dalam garis yang bertitik tolak pengalaman dahulu, dengan Yesus, seorang manusia, dalam refleksi umat seolah-olah menjadi ilahi, semakin ditempatkan di pihak Allah. Yesus menjadi seorang manusia yang diilahikan. Hanya jelaslah bahwa Yesus seorang manusia lain dari sipapun. Ia sungguh-sungguh unggul, seorang tokoh yang bertindak sebagai utusan Allah, sebagai wakil dan kuasa Allah sendiri dan atas dasar itu sedikit banyak disamakan dengan Allah yang menghubungi manusia. (Groenen ofm 1987, 67). 
BONAFIDE: Jurnal Teologi dan Pendidikan Kristen

www.jurnal.sttissiau.ac.id/Volume 1/Nomor 1/Juni 2020/hal. 144-164

Selain Bavinck yang mewakili kubu Reformed, Bloesch mewakili teolog evangelical (Injili) mendasari pandangan mereka sesuai dengan kesaksian Alkitab; "Atas dasar kesetiaannya pada kesaksian Kitab Suci (Alkitab), gereja telah menyatakan bahwa Yesus Kristus adalah benar Allah dan benar manusia yang sejati dalam satu pribadi”. (Bloesch 2006, 127). Semua pandangan ini didasarkan atas bukti-bukti Alkitab dan juga melalui hasil keputusan sebagai konsesus dalam konsili bapak gereja di Chalsedon (451 M). Horton menguraikan hasil konsili Chalsedon sebagai berikut:

Konsili Chalsedon (451) Menegaskan bahwa Kristus adalah "Satu pribadi dalam dua kodrat." Kitab Suci menafsirkan, pengakuan iman mengakui bahwa Yesus Kristus adalah benar-benar Allah ("Sehakikat dengan Bapa sesuai dengan Ketuhanan") dan juga benar-benar manusia ("dari jiwa dan tubuh yang masuk akal, setara dengan kita sesuai dengan kemanusiaan; dalam segala hal seperti kita Ia tanpa dosa"). Ia lahir dari Sang Bapa sebelum segala zaman sejauh menyangkut kealahan-Nya, Ia sama dahulu dan sekarang sampai selama-lamanya untuk kita dan keselamatan kita, lahir dari Maria anak dara dan ibunda Allah, sesuai dengan kemanusiaan; satu-satunya dan sama adalah Kristus, Putera, Tuhan, Yang diperanakkan, untuk diakui dalam dua kodrat, Tidak tercampur, tidak dapat diubah, tidak dapat dipisahkan, dan tidak dapat dibagikan." Oleh karena itu, Kedua kodrat ini yang dapat dibedakan oleh karena kesatuan, tetapi khusus oleh ciri khas kodrat masing-masing dipertahankan dan tetap menjadi satu di dalam satu pribadi yang tetap ada dan satu tabiat, bukan sebagai sebagaian atau terpisah di dalam dua pribadi, tetapi satu-satunya Anak dan Anak Tunggal Allah, Firman Allah, Tuhan Yesus Kristus. (Horton 2011, 680).

Dari hasil keputusan di Chalcedon tersebut, maka seharusnya kita menerima pandangan yang alkitabiah bahwa Yesus adalah Allah dan juga manusia sejati yang berdiam dalam satu pribadi. C. Ryie menyatakan: "Oleh karena itu, dengan mengikuti bapak-bapak suci, kita semua sepakat untuk mangajar manusia mengakui seorang yaitu Putra itu, Tuhan kita Yesus Kristus, yang sekaligus sempurna dalam ke Allahan dan sempurna dalam kemanusiaan.” 
BONAFIDE: Jurnal Teologi dan Pendidikan Kristen

www.jurnal.sttissiau.ac.id/Volume 1/Nomor 1/Juni 2020/hal. 144-164

(Ryrie 2010, 334). Aksentuasi terhadap natur keilahian Yesus menurut teologi reformed dan Injili jelas didasarkan pada bukti Alkitab.

\section{Ajaran Alkitab Mengenai bukti Ketuhanan Yesus (Internal Evidance)}

Alkitab sebagai sumber terpercaya memberikan kepada kita catatan dan kesaksian penting mengenai evidensi natur ilahi Yesus dalam berbagai cara. Ia lebih sekedar seorang manusia bisa. Karena Yesus benar-benar pernah hidup dalam sejarah manusia sehingga sangat wajar bila ada pendapat atau kesaksian mengenai Dia termasuk orang-orang pada zaman itu yang pernah berada di sekitar-Nya. Di antaranya adalah kesaksian dan pengakuan Elizabeth yang dipenuhi Roh Kudus (Luk.1:43), penjahat yang disalibkan bersama-Nya (Luk.23:42), kepala pasukan yang menyalibkan-Nya (Mat.27:54), kesaksian malaikat Gabriel (Luk.1:32; Mat.1:23; 9:5-6), kesaksian Allah Bapa (Mat.3:17), bahkan kesaksian setan-legion (Mrk.5:7). Berkhof menegaskan bahwa dalam Perjanjian Lama terdapat nubuatan tentang Mesias ilahi berdasarkan ayat-ayat berikut: Mzm.2:6-12 (Ibr.1:5); 45:6,7 (Ibr.1:8,9); 110:1 (Ibr.1:13); Yes. 9:6; Yer.23; Dan.7:13; Mi.5:2; Za.13:7; Mal.3:1. Dalam Perjanjian Baru ditemukan di dalam Surat-surat Paulus dan juga Surat Ibrani (Rm.1:7; 9:5; 1 Kor.1:1-3; 2:8; 2 Kor 5:10; Gal.2:20; 4:4; Flp.2:6; Kol.2:9; 1 Tim.3:16; Ibr.1:1-3,5-8; 4:14; 5:8, Tulisan-tulisan Yohanes (Yoh.1:1-3,14,18; 2:24,25; 3:16-18, 35,36; 4:14,15; 5:18, 20-22; 25-27; 11:41-44; 20:28; 1 Yoh.1:3; 2:23; 4:14-15; 5:5, 10-13, 20) dan dalam Injil Sinoptik (Mat.5:17; 9:6; 11:1-6, 27; 14:33; 16:16,17; 28:18; 25:31; Mrk.8:38). (Berkhof 2009). 
Bukti-bukti internal yang lain bisa kita lihat ketika Yesus membuat berbagai mukjizat dalam pelayanan-Nya, antara lain menyembuhkan orang sakit, membangkitkan orang mati, dan mengusir setan. Hal ini menimbulkan perpecahan dalam kalangan orang-orang Farisi dan Ahli Taurat. Dalam Yohanes 9:16 terlihat jelas bagaimana silang pendaat itu bisa diperlihatkan. Alkitab dengan jelas dan tegas menyatakan bahwa Yesus adalah Tuhan dan sekaligus manusia. Kolose 2:9 “Sebab dalam Dialah berdiam secara jasmaniah seluruh kepenuhan ke-Allahan". Ini dikenal sebagai doktrin persatuan Hypostatik di mana satu pribadi Yesus memiliki dua natur: Tuhan dan manusia.

\section{Gelar Anak Allah dan TUHAN}

Alkitab memberikan kepada kita kesaksian penting dari ajaran para rasul tentang Yesus. Gelar atau predikat yang diberikan kepada-Nya cukup bervarian. Ia disebut sebagai Guru, Anak Daud, Anak Manusia, Mesias, Tuhan, Anak Allah, dan Kristus. Penamaan atau pemberian gelar tersebut selalu dihubungkan dengan peristiwa-peristiwa khusus yang dilakukan Yesus dalam kesempatan-kesempatan khusus.

Penyebutan gelar Mesias, Tuhan, Anak Allah dan Kristus sebagaimana dijelaskan di atas secara eksplisit menegaskan keilahan Yesus. Menurut Schreiner, peyebutan Anak Allah berarti Yesus adalah Israel sejati, dan Mesias, Anak Daud yang dijanjikan. Namun, para penulis Injil melihat makna yang lebih mendalam dalam sebutan "Anak Allah". Yesus juga memiliki hubungan yang unik dan istimewa dengan Allah. (Schreiner 2015). Mendukung pernyataan Schreiner di atas, Morris menegaskan, 
Gelar Anak Allah yang diberikan oleh Yohanes kepada Yesus adalah Istilah yang bisa dikenakan pada seorang saleh untuk menunjukkan hubungan istimewanya dengan Allah. Ia tentu menggunakannya dengan makna tertinggi. Di mata Yohanes, kedudukan Yesus sebagai anak (Son) itu istimewa, dan jelas berbeda dengan kedudukan orang saleh yang juga sebagai anak (children). Istilah Monogenes, yang dipakai untuk Yesus sebanyak empat kali. Kata ini diterjemahkan dengan "only-begotten" (KJV=Anak Tunggal), namun makna dari kata ini adalah "Satu-satunya", "Unik". Kata ini tidak ada hubungannya dengan soal keturunan. (Morris 2006, 321-22).

Menurut Guthrie, kata Yunani Monogenes yang disebutkan di atas mengenai keadaan Yesus sebagai Allah yang sudah ada sebelum segala sesuatu. Jika kata itu ditafsirkan sebagai gelar, hal itu menarik perhatian pada keadaan Yesus sebagai Anak Allah dalam arti yang unik. (Guthrie 2011).

Selain gelar Anak Allah, gelar Tuhan juga diberikan kepada Yesus. Rasul Paulus dalam Surat-surat kirimannya seringkali menggunakan istilah tersebut. Schreiner menjelaskan bahwa: Keallahan Yesus diteguhkan melalui frasa "Kesetaraan dengan Allah" dalam Filipi 2:6 sebab kesetaraan Yesus dengan Allah merupakan cara lain untuk mengatakan “rupa Allah”. (Schreiner 2015, 220).

\section{Klaim Diri Yesus}

Ada saja pandangan yang keberatan bahwa Yesus tidak pernah mengklaim diri-Nya sebagai Allah maupun Anak Allah. Namun Alkitab memberikan kepada kita informasi yang jelas bahwa Yesus tidak pernah sekalipun menolak disembah sebagai Tuhan oleh para murid dan pengikut-Nya. Berikut ini beberapa klaim diri Yesus sebagai Allah dalam beberapa nas Alkitab (Yoh.8:58; 10:17-18, 30; 14:6; Mat.9:2-3; 28:20; Luk.23:43). Berkhof menyebutkan dalam kesadaran diri Yesus sendiri Ia adalah Allah. 
Bagi mereka yang menerima kesaksian Injil memang tidak ragu-ragu lagi mengakui bahwa Yesus memang sepenuhnya sadar akan keberadaan-Nya sebagai Anak Tunggal Bapa. Ayat-ayat berikut memberi kesaksian tentang hal itu: Mat.11:27 (Luk.10:22); 21:37-38 (Mrk.12:6; Luk.20:13; 22:41-46 (Mrk.13:35-37; Luk.20:41-44); 24:36 (Mrk.13:32); 28:19. Sebagian dari ayat-ayat itu merupakan kesaksian kesadaran Mesianik Yesus, sedangkan ayat-ayat lain menyatakan bahwa Ia sadar bahwa Ia adalah Anak Allah dalam pengertian tinggi. (Berkhof 2009, 35).

Selain pernyataan Berkhof di atas, Vanhoozer memberikan sembilan faktor yang menunjuk kepada Yesus bahwa Ia adah Anak tunggal Allah. Pertama: Yesus mengacu kepada diri-Nya sendiri adalah sebagai Anak Manusia. Klaim sebagai Anak Manusia akan berpengaruh terhadap klaim keilahian. Kedua: Yesus juga membuat klaim-klaim keilahian Ketika Ia mengenakan perkataan “Akulah”, Ketiga: Yesus membuat klaim keilahian Ketika Ia mengampuni Dosa orang yang lumpuh dalam Markus 2, satu-satunya orang yang mengatakan hal demikian dengan begitu berarti hanyalah Allah sendiri. Keempat: adanya klaim transcendental yang dilakukan Ketika Yesus memilih murid-murid-Nya, Kelima: mengenai pengertian Yesus akan diri-Nya sendiri datang dari cara berpikir-Nya, Keenam: Yesus menggunakan terminology Aram "Abba" atau Bapa yang terkasih, Ketika berhubungan dengan Allah, Ketujuh: adanya pengakuan dari para murid Yesus bahwa IA adalah Allah misalnya Thomas dalam Yohanes 20:28, Kedelapan: Yesus dengan jelas percaya bahwa tujuan akhir manusia bertumpuh pada apakah mereka percaya kepada-Nya atau tidak. Kesembilan: dalam Tindakan mukjizat-mujizat-Nya menyembuhkan berbagai macam penyakit dan mengusir setan, Ia menekankan bahwa apa yang dilakukan-Nya adalah tanda dari realitas datangnya Kerajaan Allah. (dalam Zacharias, Geisler, dan Lee 2011) 
BONAFIDE: Jurnal Teologi dan Pendidikan Kristen

www.jurnal.sttissiau.ac.id/Volume 1/Nomor 1/Juni 2020/hal. 144-164

\section{Pengakuan Iman Para Murid Yesus}

Para Murid sebagai saksi mata, telinga bahkan saksi mati akan karya keselamatan yang dikerjakan Yesus juga memberikan kesaksian tentang keilahian bahwa Yesus sebagai Tuhan dan Kristus. Pengakuan Rasul Petrus dalam Matius 16:16 (Engkaulah Mesias Anak Allah yang hidup), Yesus sebagai Tuhan semua orang (Kis.10:36), Pengakuan Natanael dengan menyebut Yesus sebagai Rabbi, Engkau Anak Allah, Raja orang Israel (Yoh.1:49). Pengakuan Thomas: Ya Tuhan ku dan Allah-ku (Yoh.20:28). Para murid menyatakan bahwa Yesus lebih dari sekedar manusia biasa. Ia bersifat Ilahi (Yoh.1:1; Why.1:8, 5; Mat.16:16; Luk.2:34; Yoh 20:28). Paulus menyatakan bahwa Ia adalah Allah dan Juruselamat kita (Flp.2:6, Tit.2:13). Dia adalah Tuhan dan Raja di atas segala raja. Sebutan “Tuhan” bagi orang Yahudi seperti Yohanes hanya akan diberikan kepada Allah (Why.19:16).

Orang Kristen Yahudi abad pertama juga mengalami dilema sebab pengakuan mereka bahwa Yesus adalah Tuhan tentu akan bertentangan dengan konsep teologis mereka terhadap monotheisme Yahudi dan kultus penyembahan kepada kaisar yang telah disembah di dalam kekaisaran Romawi saat itu. Tantangan dari agama Yahudi sendiri adalah mereka akan dikucilkan bila percaya bahwa Yesus adalah Tuhan atau Mesias. Tidak hanya itu saja tetapi orang Kristen dilarang keras untuk memberitakan nama Yesus. Bagi yang melanggar maka konsekuensi dari hukuman mereka adalah dipenjarakan dan bahkan tidak segansegan dibunuh. (bnd. Yoh.9:22; Kis.4;16:19-40;17:7). Kekristenan dalam konteks 
dunia Greco-Roman abad pertama merupakan suatu pertanggungjawaban iman yang sulit. Hagner menegaskan:

Pengakuan iman Kristen bahwa Yesus adalah Tuhan dan juruselamat segera membawa mereka ke dalam ketegangan kultus kaisar. Karena kedua hal tersebut diklaim oleh kaisar. Penegasan iman Kristen bahwa Yesus sebagai Tuhan pasti membawa kesetiaan mereka kepada kaisar dipertanyakan. (Hagner 2012, 46).

Meskipun pengakuan Yesus sebagai Tuhan adalah tanggungjawab iman yang berat namun dalam ajaran Kristen mula-mula terus dijunjung tinggi oleh para pengikut-Nya. Bray menegaskan bahwa:

Pada masa-masa awal sejarah gereja, pernyataan-pernyataan pengakuan tentang Yesus sederhana dan bersahaja, tetapi pernyataan-pernyataan itu selalu ada. Sejak awal tidak seorang pun dapat bergabung dengan komunitas Kristen tanpa mengakui Yesus sebagai Tuhan dan Juruselamat (Kis.2:38). Jika ada satu sikap bungkam dalam gereja mula-mula tentang pendeskripsian Yesus sebagai "Allah" tanpa kualifikasi lebih lanjut, ini mungkin disebabkan oleh kebiasaan-kebiasaan monotheisme Yahudi yang berurat akar, digabung dengan kebutuhan untuk mempertahankan monotheisme itu di dalam suatu dunia dimana pluralitas allah merupakan norma. (Gerald 2019, 247).

Jika demikian, apa yang dimaksudkan oleh Yohanes, Paulus, bahkan Petrus ketika mengatakan bahwa Yesus Kristus adalah Tuhan? Apakah pernyataan demikian tidak berlawanan dengan kultus penyembahan kepada kaisar romawi pada waktu itu? Selain itu juga yang menjadi pertanyaan penting: bukankah pernyataan Yesus adalah Tuhan atau Allah sangat bertentangan dengan ajaran Yudaisme yang pernah dianut sebelumnya? Mengapa mereka meninggalkan monetheisme Yahudi dan mengikuti ajaran Yesus bahkan menyembah-Nya sebagai Tuhan dan Kristus? Jelaslah bahwa mereka adalah orang yang dekat dengan Yesus sehingga mengalami langsung segala perbuatan Yesus yang benarbenar menunjukkan sifat keilahian-Nya. 


\section{Yesus, Manusia dan Tuhan: Apakah Layak Dipercaya?}

Mengakui dan menerima Yesus sebagai Tuhan adalah sebuah pertanggungjawaban iman yang berat. Sebab pokok ini adalah persoalan yang mendasar. Rasio manusia seakan tidak berdaya menjangkau bagaimana mungkin seorang manusia pada saat yang sama juga adalah Tuhan. Namun Alkitab memberikan catatan dan kesaksian secara eksplisit mengenai pokok iman ini. Jelas bahwa jika dipikirkan maka kita tidak mampu menyelami rahasia Allah yang sudah bersembunyi berabad-abad lamanya sebagaimana ungkapan Paulus dalam Surat Kolose 1:26-27. Yesus Kristus itu adalah rahasia Allah yang telah dinyatakan kepada manusia. Namun tidak semua bisa menerimanya. Knitter menegaskan: "Pernyataan Kristen yang mengenai Yesus sebagai perwujudan realitas dan rencana Allah yang final atau tidak tertandingi secara mendasar merupakan persoalan hati, bukan persoalan kepala". (Knitter 2005, 112). Artinya tindakan persetujuan dan penerimaan adalah masalah keyakinan dalam hati (iman) bukan pikiran. Paulus secara jelas menyatakan bahwa pemberitaan tentang Kristus yang disalibkan, untuk orang-orang Yahudi merupakan suatu batu sandungan dan untuk orang-orang bukan Yahudi suatu kebodohan. Tetapi untuk mereka yang dipanggil, baik orang Yahudi maupun orang bukan Yahudi, Kristus adalah kekuatan Allah dan Hikmat Allah (1 Kor.1:23-24). Meskipun demikian, Alkitab sangat gamblang memberikan penghiburan bahwa berbahagialah mereka yan tidak kecewa dan menolak Yesus. Ini sebuah penghiburan yang tak tertandingi dalam iman Kristen. 
C. S. Lewis, memberikan tiga opsi sebutan yang dikenakan kepada Yesus.: Pertama, Yesus Sebagai Pembohong, Kedua, Orang gila ketiga, atau memang benar DIA adalah TUHAN. Berikut ini pernyataan-nya:

"Di sini saya berusaha mencegah siapapun untuk mengatakan yang sungguh-sungguh bodoh yang sering dikatakan seseorang tentang Dia, yaitu 'Saya siap menerima Yesus sebagai seorang guru moral yang agung, tetapi saya tidak dapat menerima pernyataan-Nya bahwa Dia adalah Allah.' Justru itulah satu-satunya hal yang tidak boleh kita katakan. Seseorang yang cuma manusia saja yang mengatakan hal-hal yang Yesus katakan, tak mungkin seorang guru moral yang agung. Pastilah dia seorang gila - setingkat dengan orang yang mengatakan dirinya telur rebus - atau tentulah dia iblis sendiri yang berasal dari neraka. Anda harus menentukan pilihan anda. Entah orang ini Anak Allah, atau orang gila atau sesuatu yang lebih buruk lagi. (Lewis 2001, 52).

Selanjutnya Kevin Vanhoozer dengan mengatakan: "jika kita tidak mengaku Yesus sebagai Kristus, maka entah Ia berbohong terhadap identitas-Nya sendiri atau kita yang berbohong”. (dalam Zacharias, Geisler, dan Lee 2011, 88). Bukti-bukti dengan jelas menunjukkan bahwa Yesus adalah Tuhan dan Allah, tetapi sejumlah orang tertentu menolak bukti yang jelas ini karena implikasiimplikasi moral yang terlibat dengannya. Mereka tidak mau menghadapi tanggung jawab atau implikasi dari menyebut Yesus sebagai Tuhan dan Allah. Lalu bagaimana dengan kita? Apakah percaya Yesus sebagai manusia sekaligus Tuhan?

\section{KESIMPULAN}

Pengakuan Yesus sebagai manusia tidaklah menjadi keberatan bagi banyak orang, namun pengakuan sebagai Tuhan dan Allah tentu banyak dikecam. Namun Alkitab mengajarkan bahwa Yesus adalah satu pribadi yang memiliki dua natur yakni sebagai Allah dan manusia. Oleh karena itu, melalui tulisan ini 
penulis memberikan kesimpulan terhadap doktrin kristologi kaum adopsionis yang menyangkali prinsip natur keilahian Yesus.

Pertama, Alkitab secara gamblang memberikan bukti-bukti yang kuat mengenai natur keilahian Yesus sebagai Tuhan selain menekankan kemanusiaanNya. Kedua, bukti-bukti keilahian Yesus yang melebihi manusia biasa terlihat dari tanda-tanda ajaib yang dilakukan-Nya (mujizat-mujizat). Ketiga, persekutuan dalam relasi triadis (tritunggal) menggambarkan hubungan yang istimewa dan unik antara Yesus dan Bapa serta Roh Kudus sebagai Allah yang kekal. Keempat, Yesus sendiri sadar akan status diri-Nya sebagai Anak Allah atau Allah dengan klaim-klaim atas diri-Nya seperti: "Aku berkata kepada-mu, "Dosamu telah diampuni", "Aku adalah" yang seyogyanya hanya bisa dilakukan oleh Allah. Kelima, adanya pengakuan dari para saksi mata, telinga dan saksi mati tentang Yesus yakni para rasul dan murid yang lain bahwa Yesus adalah Tuhan. Keenam, selain adanya kesaksian dan pengakuan dari para murid Yesus, sejarah gereja pada abad mula-mula bakkan tradisi-tradisi gereja melalui pengakuan imannya (Credo) juga tetap mendukung natur keilahian Yesus.

Penyangkalan akan natur keilahian Yesus sebagaimana ajaran kaum adopsionis adalah ajaran yang salah karena tidak sesuai dengan ajaran Alkitab bahkan menyangkali keilahian dan pre-eksistensi-Nya sebagai Allah dan pribadi kedua dalam relasi Triadis. Anggapan bahwa Yesus hanyalah manusia biasa dapat diruntuhkan dengan berbagai mujizat yang dilakukan oleh Yesus sebab manusia biasa tidak bisa melakukan hal-hal ajaib serupa dengan Yesus. Selain itu juga Yesus dipandang sebagai manusia yang bijaksana, baik hati, melakukan perintah 
Allah dengan sempurna, dan taat kepada Allah. Oleh karena itu, Yesus diadopsi oleh Allah dan dipersatukan dengan Roh Allah. Yesus diangkat menuju tingkat ilahi sebagai Anak Allah. Setelah itu, Yesus disembah sebagai Tuhan tidaklah berdasar karena pribadi Yesus hanya dilihat dari natur kemanusiaan-Nya saja, dan mengabaikan natur keilahian-Nya. Ia adalah manusia yang walaupun dicobai namun tidak berdosa (Ibr.4:15). Bahkan tetap taat sekalipun dicobai karena dosa sangatlah bertentangan dengan natur keilahian sebagai yang kudus dari Allah yang pada saat inkarnasi-Nya tetap tidak tercampur, tidak diubahkan, tidak dipisahkan dan tidak dibagikan dengan natur kemanusiaan-Nya melainkan kedua natur tersebut tetap dipertahankan dalam satu pribadi Yesus. Ketuhanan Yesus menurut kaum adopsionis seolah-olah baru diberikan setelah karya keselamatan yang dikerjakan ini sangat bertentangan dengan kesaksian Alkitab.

Selanjutnya Pandangan ini mengajarkan bahwa Kristus telah menerima ujian dari Allah dan setelah lulus ujian dia menerima baptisan, lalu kemudian diberikan kuasa-kuasa supranatural oleh Allah dan diadopsi atau diangkat sebagai Anak Allah. Sebagai upah dari kesukses-suksesan-Nya dan pribadi Yesus Kristus yang sempurna, Dia dibangkitkan dari kematian dan lalu angkat ke dalam Allah Tritungal. Semua anggapan ini tidaklah berdasar karena menyangkali kemahakuasaan Yesus sebagai Allah, bahkan menyangkali kesaksian Perjanjian Lama mengenai Pre-Eksistensi Yesus sebagai Allah yang eksistensi-Nya telah ada sejak mulanya (Yoh.1:1). Bahkan relasi persekutuan Tri Tunggal sudah terjadi sebelum inkarnasi Yesus bukan sebaliknya yakni sejak mulanya yang disaksikan di dalam peristiwa penciptaan kosmos dan manusia (Kej.1). 
Jadi semua bentuk kristologi miring dari bidat-bidat Kristen yang akhirakhir ini semakin gencar diajarkan perlu diuji dengan kesaksian Alkitab. Semoga kita tetap berpegang teguh kepada kebenaran Alkitab sebagai Firman Allah yang berotoritas bahwa Yesus adalah Tuhan dan manusia. Akhirnya, sebagai pernyataan iman bersama mengutip salah satu doxologi Rasul Paulus yang paling agung mengenai keilahian Yesus: "Itulah sebabnya Allah sangat meninggikan Dia dan mengaruniakan kepada-Nya nama di atas segala nama, supaya dalam nama Yesus bertekuk lutut segala yang ada di langit dan yang ada di bawah bumi, dan segala lidah mengaku: "Yesus Kristus adalah Tuhan," bagi kemuliaan Allah, Bapa (Flp.2:9-11). Laus Deo...Soli Deo Gloria!

\section{DAFTAR PUSTAKA}

Ambarsari, Trivena. 2007. Studi Korespondensi Reformed Injili Indonesia (SKRII). 2 ed. Surabaya: Momentum.

Bavinck, Herman. 2011. Reformed Dogmatics. Diedit oleh John Bolt. Grand Rapid, Michigan: Baker Academic.

Berkhof, Louis. 2009. Teologi Sitematika Vol.3: Doktrin Kristus. Surabaya: Momentum.

Bloesch, Donald G. 2006. Essentials of Evangelical Theology. USA: Hendrickson Publishers.

Browning, W.R.F. 2011. Kamus Alkitab: A Dictionary of the Bible. BPK Gunung Mulia.

Budiono. 2005. Kamus ilmiah populer internasional: materi politik, ekonomi, hukum, sosial, budaya, agama. Surabaya: Alumni.

Gerald, Bray. 2019. Allah Telah Berfirman (Sejarah Theologi Kristen Jilid Satu). Surabaya: Momentum.

Groenen ofm, C. 1987. Sejarah Dogma Kristologi: Perkembangan Pemikiran 
tentang Yesus Kristus pada Umat Kristen. Yogyakarta: Kanisius.

Guthrie, Donald. 2011. Teologi Perjanjian Baru I. Jakarta: BPK Gunung Mulia.

Hagner, Donald A. 2012. The New Testament (A Historical and Theological Introduction). Grand Rapid, Michigan: Baker Academic.

Horton, Michael. 2011. The Christian Faith (A systematic Theology for Pilgrims On the Way). Michigan: Zondervan.

Knitter, Paul F. 2005. Menggugat Arogansi Kekristenan. Yogyakarta: Kanisius.

Lewis, Clive Staples. 2001. Mere Christianity. HarperCollins e-books.

Macleod, Donald. 1998. The person of Christ. InterVarsity Press.

Morris, Leon. 2006. Teologi Perjanjian Baru. Malang: Gandum Mas.

Nazir, Mohammad. 2007. Metode Penelitian. Jakarta: Ghalia Indonesia.

Pelikan, Jaroslav. 1993. Christianity and Classical Culture. Grand Rapid, Michigan: Vail Ballou Press.

Rosner, Brian S., T. Desmond Alexander, Graeme Goldsworthy, dan D. A. Carson, ed. 2000. New Dictionary of Biblical Theology. IVP Academic.

Ryrie, Charles C. 2010. Teologi Dasar. Yogyakarta: Penerbit Andi.

Schreiner, Thomas R. 2015. New Testament Theology. Yogyakarta: Andi Offset.

Velduis, Henri. 2010. Kutahu yang ku percaya: Sebuah Penjelasan tentang Iman Kristen. Jakarta: BPK Gunung Mulia.

Wellem, F. D. (Frederiek Djara). 2004. Kamus sejarah gereja. BPK Gunung Mulia.

Wongso, Peter. 2001. Sejarah Gereja. Malang: SAAT.

Zacharias, Ravi, Norman L. Geisler, dan Strobel Lee. 2011. Who Made God? (Siapa yang Menciptakan Allah). Bandung: Pionir Jaya. 